Dept. of Anat., Fac. of Med., Kyoto Univ., Koyto.

\title{
The Effect of Ethylurethan on The Mitotic Activity of Precarti- lage Cells in The Hand Plates of Mouse Embryos.
}

\author{
エチルウレタンのマウス胎仔手板前軟骨細胞の核分裂に対する效果.
}

\section{Hiroaki NIMURA and Hideo NISIMURA.}

\author{
仁 村博晃と西村秀雄.
}

(Received April 4, 1960.)

It has been known for many years that ethylurethan is a poison which acts specifically on mitotic activity. Recently it was shown by NISHIMURA et al. (1958) that the transitory administration of ethylurethan to pregnant mice induced in their fetuses severe skeletal anomalies and a high incidence of digital anomalies. The present investigations were carried out on the mitotic phase of the primordial digits by the administration of ethylurethan to clarify the developmental processes in the formation of digital malformations.

\section{Material and Methods.}

For this study 38 female mice 3-10 months old from a colony in our laboratory were used; these originated from a Japanese hybrid strain and were maintained in our laboratory for 3-5 generations.

These mice were mated with adult male mice 3-6 months old and those whose pregnancies were confirmed, were given an intraperitoneal injection of $10 \%$ aqueous ethylurethan (MERCK preparation) at one of three different times on the 12th day of gestation, namely 7 hours, 4 hours or 1 hour before 4 p. m. (i. e. at 9 a. m., 12 a. m. or 3 p. m. respectively) in a dose of $0.15 \mathrm{mg}$ per $\mathrm{gm}$ of body weight.

The treated mice were sacrificed by chloroform anesthetization at $4 \mathrm{p}$. m. and the fetuses were fixed in cold $\left(5-8^{\circ} \mathrm{C}\right)$ BOUIN's fluid. Next, both hand plates were embedded in paraffin, sectioned serially parallel to the palmar surface and stained with HEIDENHAIN's iron hematoxylin. 10,000 precartilage cells of the hand plate specimen were randomly picked and the number of mitosis in each mitotic stage was counted. To avoid counting same cell twice only every 4 th section was used.

As controls, mice on the 12 th day of gestation obtained in the same way as mentioned above, but not treated were used. The number of mitoses in the precartilage cells was counted by the same procedure.

\section{Results.}

The average number of precartilage cells in each stage of mitoses and their mean error were calculated, the results of which are as shown in table 1 . 
Table 1. Effect of single intraperitoneal injections of ethylurethan on pregnant mice of the 12th gestational day, in the dosage of $1.5 \mathrm{mg}$ per gm of body weight, on the mitotic activity of the precartilage cells of the hand plate of mouse embryos.

\begin{tabular}{|c|c|c|c|c|c|c|c|}
\hline & \multirow{2}{*}{$\begin{array}{ll}4 & 0 \\
0 & 8 \\
0 & 0 \\
0 & 8 \\
2 & 0\end{array}$} & \multicolumn{6}{|c|}{$\begin{array}{l}\text { Average number of mitoses in } 10,000 \text { precartilage cells } \\
\text { and mean error }\end{array}$} \\
\hline & & Prophase & Metaphase & Anaphase & Telophase & $\begin{array}{l}\text { Reconstruc- } \\
\text { tion phase }\end{array}$ & Total \\
\hline Control & 11 & $6.36 \pm 1.64$ & $78.09 \pm 7.85$ & $10.0 \pm 1.24$ & $8.27 \pm 1.23$ & $4.73 \pm 0.65$ & 107.45 \\
\hline $\begin{array}{l}1 \text { hour after } \\
\text { administration }\end{array}$ & 9 & $4.11 \pm 0.90$ & $73.88 \pm 7.23$ & $8.11 \pm 1.70$ & $7.11 \pm 1.02$ & $4.33 \pm 0.57$ & 97.54 \\
\hline $\begin{array}{l}4 \text { hours after } \\
\text { administration }\end{array}$ & 9 & $5.22 \pm 1.61$ & $78.44 \pm 11.23$ & $11.88 \pm 2.83$ & $7.0 \pm 0.42$ & $3.22 \pm 0.95$ & 105.74 \\
\hline $\begin{array}{l}7 \text { hours after } \\
\text { administration }\end{array}$ & 9 & $0.11 \pm 0.10$ & $28.88 \pm 3.35$ & $2.55 \pm 0.63$ & $2.33 \pm 0.38$ & $1.77 \pm 0.26$ & 35.64 \\
\hline
\end{tabular}

According to table 1, in the control group, the number of mitoses is highest in the metaphase, following which are anaphase, telophase, prophase and the reconstruction phase. This tendency is recognized also in the experimental group. The numbers of mitoses in the treated group are not different from those of the control group in one and 4 hours after administration, but in the 7 hours after administration, a drastic fall was recognized in each stage of mitoses.

\section{Discussion.}

According to DUSTIN (1947) and GUYER and CLAUS (1947) ethylurethan belongs to mitotic poisons of the trypaflavin type. DUSTIN (1947) showed that this chemical inhibits the mitotic activity of glandular cells of the intestine, and that cytological disturbances such as pyknosis or degeneration occurs 8 hours after injection. GUYER and CLAUS (1947) recognized that in rats or mice the corneal cells in every stage of mitoses decreased after an intraperitoneal injection of ethylurethan. BÜCHER (1949) also recognized that ethylurethan inhibited the mitotic activity of the cultured fibroblasts of rabbits.

In the present experiment, a conspicuous decrease of mitotic activity of the precartilage cells in the hand plates of mouse embryos was recognized in 7 hours after administration of ethylurethan, and this arresting effect was found in each stage of mitoses. This finding is in accord with the effect of trypaflavin ty pe poisons mentioned by DUSTIN (1947) and GUYER \& CLAUS (1947). According to NISHIMURA et al. (1958), and KANAMORI (1958), ethylurethan induces digital anomalies of the mice embryos frequently after injection of this chemical to pregnant mice on the 12 th gestational day. When the results of the present experiment is considered, it is possible that these anomalies are associated with the inhibition of cell proliferation of the developing bone primordia.

\section{Summary.}

The effect of transplacental administration of ethylurethan on the mitotic ac- 
tivity in the hand plates of mouse embryos was investigated. On the 12 th day of gestation, $10 \%$ ethylurethan was injected intraperitoneally to pregnant mice, and on various hours up to 7 hours after injection, a number of precartilage cells in each stage of mitoses was counted. In 7 hours after administration, a conspicuous decrease of mitoses was recognized in all the stages. Namely, ethylurethan may have shown the effect of the trypaflavin type toxins.

It may be considered that digital malformations of embryos induced by injection of ethylurethan was caused by the inhibition of mitotic activity in the cells of the bone primordia of digits.

\section{内 容自抄.}

エチルウレタンが細胞分裂に対し特異的に働く毒物であることは古くから知ら れている，沂年 Nishimura 等 (1953) によってェチルウレタンの妅娠マウスに対 する一過性適用がその胎仔に高い頻度で多型且つ強度の指趾，その他骨系統の命 形を形成するととが明かとされた。

このような指異常の初期の炎生過程を明かにすることを企図し，エチルウレタ ン通用後短時間後における指原基の核分裂の状況を調査した。

姬娠 12 日に $10 \%$ エチルウレタン水溶液の腹腔内注射を行い，その後 7 時間迄 種々の時間を経た際の胚の手板の分裂各期の前軟骨細胞を求めたところ, 投与 7 時間後に扔いて各期共に顕著な㤥分裂数の低下を認めた。故にエチルウレタンは この埸合トリパフラビン型の效果を示したと認められる。従ってエチルウレタン の投与により惹起される胚の指骨異常の発生過程には，その原基細胞の核分裂の 阻碍が与るものと考えられる.

\section{References.}

Bücher, O.: Die Wirkung von Äthylurethan auf die mitotische Zellteilung, untersucht an Gewebekulturen in vitro. Helvet. Physiol. et Pharmacol. Acta 7 (1949). S. 37-54. - Dustin, P.: Some new aspects of mitotic poisoning. Nature (London). 159 (1947). P. 794-797. - Guyer, M. F. and P. E. Claus: Effects of urethane (ethylcarbamate) on mitosis. Proc. Soc. ex per. Biol. Med. 64 (1947) P. 3-5. - Kana mori, H.: Embryological studies on various malformations in the offspring of pregnant mice treated with ethylurethan. II. The developmental process of the digital anomalies. (Jap. with Engl. abstr.) Kaibo Z. (Acta. anat nipponica). 33 (1958). P. 64-73. - Nishimura, H. and M. Kuginuki : Congenital malformations induced by ethylurethane in mouse embryos. Okajimas Fol. anat. jap. 31 (1958). P. 114. 